\title{
The 1899 Orange Free State football team tour of Europe: 'Race', imperial loyalty and sporting contest
}

\author{
Chris Bolsmann ${ }^{1}$ \\ School of Languages and Social Sciences, Aston University, Birmingham, UK
}

\begin{abstract}
In September 1899 an association football team from Bloemfontein in the Orange Free State, South Africa, arrived in the United Kingdom. The team comprised 16 black South Africans who played under the auspices of the whites-only Orange Free State Football Association and was the first ever South African football team to tour abroad. In a four month tour the team played 49 matches against opposition in England, France, Ireland, Scotland and Wales. A small, but growing body of work focuses on black sport and football in particular and the 1899 tour is referred to in passing in a few publications, although none have attempted to uncover details of the team or the matches that were played in Europe. This article attempts to do this by drawing on a range of newspaper and archival sources in South Africa and the United Kingdom and argues the case for the significance of this team for South African sports history in general and for football history in particular.
\end{abstract}

\section{Introduction}

Four weeks prior to the outbreak of the South African War, fought between Britain and the combined forces of the Orange Free State Republic and South African Republic, an association football match was played at St James' Park, Newcastle-upon-Tyne, between Newcastle United and a touring South African team, the Orange Free State Kaffir Football Club. ${ }^{2}$ Watched by 6,000 spectators, the black South Africans lost the game 6:3. ${ }^{3}$ This was the first time a South African association football team had played abroad. It was the opening game of a four month, 49-match tour of England, France, Ireland, Scotland and Wales. The Orange Free State team was pitted against superior opposition 
and as the tour progressed it was evident that it was totally out of its depth against the professional and amateur first class opposition.

The academic study of sport in South Africa is relatively underdeveloped, and this is particularly true with respect to football. Cricket has traditionally received the most attention, and is followed by rugby. André Odendaal has argued that 'the history of black sport has been largely undocumented' and his research has dispelled the myth 'that blacks have no real sports history'. A small but growing body of work focuses on black sport and on football in particular. ${ }^{5}$ The 1899 tour is mentioned briefly in a few publications but none have explored details of the team and the matches that were played in Europe. An attempt is made here to remedy this shortfall and argues the case for the significance of this particular touring team for football history in general and South African sports history in particular. The team from the Orange Free State was the first South African association football team to play in Europe and the second South African sports team (after the cricketers of 1894), to do so. For most of the opposing teams, the visitors were the first foreign opposition the European sides had faced; the South Africans were therefore at the forefront of globalising football at the turn of the twentieth century.

This article discusses how the press in Britain initially referred to the team in glowing terms before switching to ridicule and humiliation. It nevertheless argues that to label the tour simply in terms of an 'ethnological show' is inadequate. The colonial and imperial framework in the early twentieth century and the social Darwinism that prevailed in both Britain and South Africa during this period became all too apparent in the attitude of the British press towards the black South Africans. Despite the ridicule they suffered both on and off the pitch, the South Africans nevertheless proved to be quite popular. They played in front of relatively large crowds, adopted a pro-British/anti-Boer stance and were fêted by club administrators and officials wherever they played.

\section{Football in the Orange Free State Republic}


Football was played among whites in the Natal colony as early as the 1870s and 1880s and this region became 'the home of the game in South Africa' ${ }^{6}$ Clubs such as Pietermaritzburg County Football Club and the Natal Wasps Football Club were established in 1879 and 1880 respectively. ${ }^{7}$ The British military helped popularize the game when soldiers were stationed in Natal during the Anglo-Zulu War (1879) and the Anglo-Transvaal War (1880-1881). ${ }^{8}$ The Natal Football Association, the first such football institution in South Africa was established in 1882.

The discovery of diamonds in the 1860s and gold in 1886 initiated the development of Kimberley and Johannesburg as important mining centres and football was soon played in these areas. ${ }^{9}$ In 1892, the whites-only South African Football Association (SAFA) was founded in Kimberley to give the 'dribbling code a stronger place in sport in the country'. ${ }^{10}$ Donald Currie, the shipping magnate, donated trophies to five sports codes in South Africa during the 1880s and 1890s. The football trophy was first contested in 1892 when it was won by the Western Province Football Association (based in Cape Town) who defeated Griqualand West (Kimberley). Cecil John Rhodes was made honorary president of SAFA in 1895, ${ }^{11}$ with the presidents of the two Boer republics, Paul Kruger and Francis Reitz, serving as patrons of the association.

The first references to white football matches played in the Orange Free State Republic date back to 1876 when games were regularly played between St Andrew's College and the Cathedral Choir in Bloemfontein. In 1889 British merchants in the northern Orange Free State town of Heilbron challenged the Kroonstad players. ${ }^{12}$ In August 1890, Bethlehem played against Heilbron in Lindley. ${ }^{13}$ The football does not appear to have been of a serious nature; a newspaper reported that a game of fancy dress football was played in Heilbron, where one of the team was dressed as a 'Zulu warrior'. ${ }^{14}$ In the following year more organized football was played when the Heilbron Football Club competed against Bethlehem, Heidelberg (in the South African Republic) and Vechtkop. ${ }^{15}$ In April 1892, the first tournament was contested - Heilbron entered two teams to play against Lindley and Vechtkop. ${ }^{16}$ In July a second tournament was held with teams from Bethlehem, Heilbron and Lindley taking part. ${ }^{17}$ A further tournament was 
played later that year and included sides from Bethlehem, Harrismith and Fouriesburg. The following year Heilbron lost to the Cape Government Railways team. The popularity of the game spread and Bloemfontein newspapers began to run regular adverts for dealers such as Sowden \& Stoddart who advertised football equipment

In 1894 the southern Orange Free State diamond mining town of Jagersfontein emerged as a popular home for football in the region. Throughout the winter months of 1894, regular scratch matches were played at the Jagersfontein Cricket Club’s ground between select XI sides: Captains vs Vice-Captains; Mines vs Towns; Mother Country vs All Comers; and Home Born vs Colonial Born teams, were watched by crowds of about 200 people. In August 1894, sides representing Heilbron, Jagersfontein, Railways and Savages competed in Bloemfontein, with Heilbron emerging victorious. During the same tournament the Orange Free State Football Association (OFSFA) was formed and Fredrick Ringer of Heilbron Football Club was elected chairman. The president of the Orange Free State, F.W. Reitz was made patron of the OFSFA in 1895 and four teams, which included the newly established Ramblers of Bloemfontein, competed for the Orange Free State Challenge Cup. Heilbron was again victorious, winning the inaugural OFSFA tournament.

Football was also played in Harrismith in the north eastern Orange Free State, although they played against opposition from Ladysmith in Natal and competed for the Tatham Cup. Teams were also formed in Reitz and Fouriesburg. Prior to the 1896 season, Carl Borckenhagen, the German editor of the Bloemfontein newspaper De Express en Oranjevrijstatsche Advertentieblad presented a silver shield to the OFSFA. First teams from OFS towns competed for the Borckenhagen Shield, while the second-string sides vied for the Olds' Challenge Cup and the under-18s for the Reid's Challenge Cup. The OFSFA affiliated to SAFA in 1895 and entered the 1896 Currie Cup competition. Seven associations competed for the trophy won by Natal, with the Orange Free State second last on the final points table. 
In 1897, the popularity of football in South Africa was enhanced when the Corinthian Football Club toured the country. ${ }^{18}$ This was the first foreign tour undertaken by a British football team. ${ }^{19}$ Prior to the game played at the Recreation Ground in Bloemfontein, The Friend noted that 'we trust the Free State Association will have reason to congratulate themselves on a record gate, which will show that the Bloemfontein public appreciate the efforts made to show them the game as it is played in "Merrie England", ${ }^{20}$

Borckenhagen's De Express billed the game as 'England vs Free State'. Watched by a crowd of 1,000 people that included President Steyn, an OFSFA side lost 2:6 to the Corinthian team. The game generated receipts of $£ 90$ and at the evening banquet attended by President Steyn, the 'Volkslied' was sung, followed by 'God Save the Queen'.

The popularity of the game spread in the Orange Free State as white teams were formed in Parys, Vrededorp, Rouxville, Senekal and Bloemfontein (which fielded the Casuals and Grey College teams). Games were also played in Dewetsdorp, Ladybrand and Springfontein. ${ }^{21}$ During the 1897 season entrance fees were charged for the first time to watch regular matches. ${ }^{22}$ The Ringer Challenge Cup was contested in 1898 by northern OFS sides with the team from Reitz being the inaugural winners. The Dewar District Charity Cup was first played for in 1899. In the same year the OFS North-Eastern Association came into being with teams from Bethlehem, Heilbron, Lindley and Harrismith competing. In the late 1890s regular matches were played between 'representative' sides in Bloemfontein. These included teams called Great Britain, England, Scotland and South Africa. Attendances were good, with up to 500 spectators watching these games.

Odendaal has suggested that Africans were exposed to British sports at the informal and formal levels. They did so at the informal level through spectatorship and participation in games. At a formal level mission schools such as Lovedale, Healdtown and Zonnebloem introduced sport to Africans students. ${ }^{23}$ The first African cricket club was established in Port Elizabeth in $1869 .{ }^{24}$ Inter-town games were played and preparations were made for a cricket team to tour Britain, which never materialised. According to Odendaal, 'South Africa's industrial revolution set the stage for the rise of sport' ${ }^{25}$ Instances of black 
versus white matches were recorded not only in the eastern Cape ${ }^{26}$ but also in Orange Free State towns such as Kroonstad and Jagersfontein. ${ }^{27}$ Tim Couzens notes that football among blacks in Natal dates back to the 1890s and in Johannesburg to the turn of the century, ${ }^{28}$ while Peter Alegi suggests that black South Africans watched and probably played football with British soldiers in the besieged towns of Kimberley, Ladysmith and Mafeking during the South African War. ${ }^{29}$

\section{The tour}

Foreign football tours and visits by overseas teams to Britain were uncommon in the 1890s. Indeed, football was in its infancy outside of Britain. British teams became relatively seasoned campaigners: Marylebone FC played in France in 1893 as did Folkestone in 1895 while a Paris select played a number of games in the south of England in the same year; ${ }^{30}$ the Corinthians visited South Africa in 1897; the English Football Association sent a representative team to play in Berlin, Karlsruhe and Prague in 1899; ${ }^{31}$ and Oxford University played in Vienna in 1899 as did Southampton in $1900 .{ }^{32}$ The South African footballers were by no means the first foreign sports team to tour Britain. A Canadian team from the Western Football Association of Ontario had been there in 1888 and 1891, ${ }^{33}$ and in 1868 an Aboriginal cricket side toured Britain. ${ }^{34}$ Native American lacrosse players visited Britain in 1867, 1876 and 1883 and US professional baseball players toured in 1874 and 1888-9. British cricket sides toured South Africa in 1888, 1891, 1895 and 1898 and a South African cricket team visited Britain in 1894. British rugby teams visited South Africa in 1891 and 1894 and the South Africans sent a rugby team to Britain in $1906 .{ }^{35}$ Significantly, a New Zealand Native [Maori] Football team (of rugby players) toured Britain in $1888-1889 .{ }^{36}$ In 1899, there were at least two black professional players in Britain: John Walker of Lincoln City in the Football League and Arthur Wharton of Stalybridge Rovers in the Lancashire League. ${ }^{37}$

In April 1899, The Football Echo, in an article on 'The Latest Football Sensation', reported that the OFSFA had canvassed support from British clubs for a tour by a 'Kaffir team'. ${ }^{38}$ The newspaper confessed ignorance in the standing of the OFSFA and 
wondered 'what sort of football will these dark beauties play?' They suggested a 'Boer Football Association' might be more suitable opposition 'over here [to] do battle’. In June 1899, the Manchester Times reported on the forthcoming tour and wrote 'the team is said to be strong, the players being of splendid physique'. ${ }^{39}$ The Scottish Sport noted that they were reportedly 'big, powerful men, with a "rare turn of speed" and "considerable individual skill”' and went on to describe them as a 'determined, fine-built body of men, who have only picked up the game in the last four or five years' ${ }^{40}$ The tour was also reported in the Chicago Tribune and Brooklyn Daily Eagle in the United States and the Evening Post in New Zealand.

The team of 16 black South African players captained by Joseph Twayi departed Cape Town on the SS Gaika for Southampton. White officials M. D. 'Toffy' Roberts, Lionel Nathan, Percy Day and Arthur Moss joined the team later. Roberts and Nathan had both been active in Orange Free State football. Roberts had played for a number of years with the Jagersfontein team and represented the club at the OFSFA. Nathan was treasurer of the club and was a hotel proprietor in Bloemfontein. The six months' tour was to be financed by opposing teams who had provided guarantees and promised $50 \%$ of gate receipts. Invitations had been received for the team to play in Germany and Austria. The Friend reported: "the "boys" are said to be extremely clever at the game, and the novelty of a Kafir team is sure to command success in the old Country'. ${ }^{41}$ The press in the Orange Free State briefly reported on the tour and was generally supportive, but the same cannot be said of the Cape press. In 1894 the Cape Argus opined: 'the races are best socially apart, each good in their own way, but a terribly bad mixture', ${ }^{42}$ a direct reference to the inclusion of coloured cricketer 'Krom' Hendricks in a touring South African team. In similar vein, this time referring to the 1899 Orange Free State football tour, the Cape Argus noted:

The whole affair is farcical as it is unsportsmanlike, and smacks very much of hippodrome. Western Province "socker” enthusiast can scarcely credit the fact that a gang of Kafirs should seriously be expected to give an exhibition worthy of the name, and the British football public will soon realise this fact. Probably the 
enterprising financiers will rake in the shekels, but every white man south of the Zambesi not directly interested in the venture will regret the whole proceedings. ${ }^{43}$

Indeed the Western Province Football Association raised the issue of the tour at the SAFA annual general meeting held in Bloemfontein in September 1899. It was resolved '... that before a coloured team can be sent by an affiliated Association permission must be obtained from the South A[frican] Association' ${ }^{44}$ The Cape Times wrote that:

It is hoped that the English sporting press and public will take the same view of such a burlesque of the game as the niggers are bound to provide ... The governing body of the Association football seems to have quite ignored the proceedings in connection with this nigger troupe. This is all very well in a way, and no doubt silent contempt is often the best way [of] treating matters unworthy of notice, but the present case is, we submit one of which a very great deal of notice should be taken. The question is, what attitude did the Orange Free State Football Association take up in this matter, and how was it that the organizers of the tour were allowed to slip out of the country with their hirelings almost unheeded? ${ }^{45}$

\section{[INSERT IMAGE 1 HERE]}

G.A. Parker, manager of the 1897 touring Corinthian side and author of South African Sports (1897) was interviewed in The Football Evening News. He admitted to knowing little of the team and added that reportedly a 'strong line of distinction is drawn between the white and black population in South Africa, consequently the membership of athletic clubs is strictly confined to whites' ${ }^{46}$ On arrival in Britain and even before the first ball had been kicked, racist cartoons were published in the local press (not dissimilar to those that appeared a decade earlier during the visit of the New Zealanders). The Northern Echo called the team the "representatives from "Darkest Africa",47 and the Football Evening News noted that the team would 'dress in proper football costume, and not be allowed to carry assegais when charging' ${ }^{48}$ The Sport and Play predicted that 'much of 
the success of the tour depends on the earlier matches. If the play shown in these is of the proper standard of quality all will be well. If not, then it will be a case of lady footballers once again, and curiosity rather than skill will have to stand as the main attraction'. ${ }^{49}$

\section{'Race' and 'spectacle'}

Bernth Lindfors has argued that the 'ethnological show business ... the displaying of foreign peoples for commercial and/or educational purposes' has a long history in Europe and he dates one such exhibition of Eskimos to as far back as 1501 in Bristol. ${ }^{50}$ From the nineteenth century onwards, Africans were displayed and on occasion performed in ethnological shows. Sara Baartman was the first major ethnological display, being widely 'exhibited' in London and Paris until her death in 1815 and then displayed in a plaster cast until 1982. She 'has become a symbol of imperialist exploitation for many South Africans' ${ }^{51}$ In 1853, a group of Zulus was exhibited and performed in a show, the 'Zulu Kafir Exhibition' in London. ${ }^{52}$ And in 1879, after the British defeat at Isandhlwana, Guillermo Farini exhibited the 'Zulu Kaffir Boy' the first of a series of increasingly spectacular live African exhibitions in London. ${ }^{53}$ In the early 1890s, a black South African choir caused a stir when it performed in Britain and North America. ${ }^{54}$ The examples above fuelled the 'spectatorial lust' for the 'exotic', the 'Other' and imperial conquest; ${ }^{55}$ and it has been argued that they 'promoted and perpetuated racism’ ${ }^{56}$ Moreover, Parsons writes in his discussion of 'Clicko' the 'wild dancing Bushman' that for historians his case study 'is an exemplar of the relationship between imperialism and entertainment ... for the anthropologists it is a tale of racial paternalism and ethnic stereotyping, ${ }^{57}$

In May 1899, while preparations were underway to arrange fixtures for the Orange Free State team, a show opened in London, advertised as the 'Savage South Africa, a vivid realistic and picturesque representation of LIFE IN THE WILDS OF AFRICA' 58 Coombes refers to this as an example of the 'exhibitionary spectacle'. ${ }^{59}$ Daily performances of Lobengula's troops engaged in 'battle' with the British South Africa Company were also very popular among Londoners. The creator of the show, Frank 
Fillis, had toured southern Africa with his circus during the 1880s and recruited 200 'performers' for his London show. ${ }^{60}$ At Earl's Court these South Africans were put 'on display' in a 'Kaffir Kraal'. ${ }^{61}$ According to Shephard, 'Fillis's real novelty lay in the scale of his enterprise ... he combined the different strands ... the thrilling circus spectacle [and] ethnography laced with savage exoticism’ ${ }^{62}$ In July, it was reported that the star of the show, Prince Lobengula was to marry, the white Florence 'Kitty' Jewell. The press reported on the 'scandal' and the Daily Mail engaged in a campaign to have the show closed. ${ }^{63}$ In late August, women were barred from attending the performance at Earl's Court and Fillis moved his show to the Olympia. ${ }^{64}$ In January 1900, it was decided to close the show but was revived later that year and taken on tour around Britain.

On their arrival in Britain in 1899 certain sections of the press inevitably linked the South African touring side to the Earl's Court performers. The Football Evening News called them the 'latest Savage South Africa Exhibition'. ${ }^{65}$ In addition, the newspaper wrote: 'No arrangements have been made yet to exclude ladies from witnessing the games in which the Kaffirs take part ... they will have to dress in proper football costume' ${ }^{66}$ The Sporting Life called the team the 'wandering Earl's Court Exhibition' ${ }^{67}$ Despite initial comparisons with the Earl's Court spectacle, these ceased when the exhibition closed to go on tour. Indeed, Vasili argued, 'it would have been simple ... to portray [the team] as freak-show footballers for the amusement of the master race' ${ }^{68}$ Instead, the touring side was pitted against the premier professional and amateur teams in Britain against whom they had little chance of success. A brief glance at the results of matches played between England and foreign opposition (other than the home countries) shows that it was not until 1929 that England lost its first match to Spain, providing ample evidence of the relative dominance of the British game. ${ }^{69}$ Towards the end of September, The Sporting Life reported that 'the professional teams which they [the South Africans] have met have invariably played "exhibition games" simply getting a lead of two or three goals and then playing about to amuse the crowd and not give the strangers too severe a drubbing, ${ }^{70}$ The touring football team thus differed from the 'exhibitions' of that era in that the footballers participated in a British game against elite opposition. Despite this distinction, there was clear evidence of social Darwinism in many of the press reports. 


\section{[INSERT IMAGE 2 HERE]}

The first match of the tour was scheduled for early September, to be played against the English Football League champions, Aston Villa, in Birmingham. Joseph Chamberlain, the British secretary of state for the colonies at the time, who was a resident of the city, was to 'kick-off' the match. The Scottish Sport noted this and exclaimed 'Kick at a Kaffir! [and that] the Colonial Secretary would probably prefer to kick Kruger!'. ${ }^{71}$ However, the tourists were delayed and instead, the first match was played against Newcastle United. Within a few minutes of kick-off it was evident that the South African side, dressed in their orange shirts with black shorts, would be no match for first class British opposition. The side played with enthusiasm but 'the spectators in fact laughed more than they would do at the most successful comic opera on the boards' ${ }^{72}$ The Football News called them 'alleged footballers'. ${ }^{73}$ The team went on to lose against Sunderland, Middlesbrough and Scarborough (5:3), (7:3) and (9:3) respectively, in front of crowds that ranged between 2,000 and 4,000 people.

It was evident that the South African side lacked the technique and ability to seriously challenge first class opposition. The tour progressed to Scotland where they played and lost six matches in front of large crowds. The Scottish Sport reported that 'the Africans ought to come very well out of their engagements. The demand for novelty is not so pronounced in football as in some other sports, but the latest Colonial incursion is something out of the common' ${ }^{74}$ After the game played against Hibernian, which was watched by 3,000 people, the Scottish Sport wrote:

To treat the game between the Kaffirs and Hibs seriously would be one door off sacrilege, and to endeavour to find excuses for the persons to blame for inducing our clubs to give them fixtures would be an unpardonable breach of public confidence ... it would in all humility and seriousness suggest that the Kaffirs and the 'lady footballers' should combine their forces ... and stump some less civilised part of the world than Great Britain - France, for instance. ${ }^{75}$ 
A letter appeared in the same newspaper written by a Scot residing in Cape Town. The author questioned the strength of the visiting side and went on to remark 'Out here such a thing as a match between "white" and "black" clubs is unknown ... [and] such a team in no way represents South African football'. ${ }^{76}$ Later in September another letter was published in the Sporting Times. Thomas Coffrey of Pretoria wrote: 'Our feelings on seeing this announcement were mingled shame and disgust. To us the idea of Europeans mingling with Kaffirs on terms of equality is revolting ... a Kaffir is not a human being, and is undoubtedly a creature of a much lower origin than the Caucasian. ${ }^{77}$ The extreme views represented above are examples of the social Darwinism evident within South African society more broadly. ${ }^{78}$ The periodical South Africa had reported in 1897 that 'sport in England is a leveller in class distinctions but it has no such virtue in regard to race distinctions'. ${ }^{79}$ Moreover, citing the Daily News it added 'the man of colour, if he finds his chains fall off him when he touches soil of England, feels them riveted on again the moment he lands in one of England's colonies', ${ }^{80}$

In response to the emerging criticism of the tour the Scottish Sport published an interview with Day, Roberts and Twayi, who explained that the team officials had arranged a series of games against foreign opposition with the support of the OFSFA. A letter written by the OFSFA claimed that the 'native football team ... are officially recognized as representing the native Association players in this State and have our sanction to be advertised and play under our name'. ${ }^{81}$ This letter was used in negotiations with the English Football Association's secretary Fredrick Wall. The British press reported that the tour had been arranged to generate profits, although the team officials argued that this was not the case:

... the Kaffirs have been playing for a few years back, and showing just as good football as whites in the State. It was thought that a tour ... would do an immense amount of good to the Kaffirs and help to spread the game. It is not a speculative game at all; in fact we expect to be out of pocket, but the exhibitions which the Kaffirs have witnessed from their opponents will bear fruit ... surely Scotsmen 
and Englishmen will not grudge to sow a few seeds of the game into soil which promises to be fruitful. ${ }^{82}$

In response to a question on the reception the team received, an official remarked: 'Very good, though the crowds laugh at the efforts of the Kaffirs, and occasionally the game resolves itself into pantomime, but once the blacks get used to the turf they will get better, ${ }^{83}$ The visitors were unaccustomed to the grass turf in comparison to the hard pitches of the Orange Free State. The team initially played with inappropriate boots without studs which further hindered their game. In an interview with Twayi published in the Football Sun, he revealed that he had learnt to play football in his early twenties and was playing for a team called the Oriental. ${ }^{84}$ Twayi claimed to have established the Oriental Club in $1897^{85}$ although there is evidence that the black Oriental Cricket Club was playing cricket in the early 1890s in the Orange Free State. ${ }^{86}$ Twayi admitted that he had learnt the game when 'We saw white gentlemen play, and thought it would be a nice game'. ${ }^{87}$ He went on to say that they played on Wednesday afternoons as this was the only free time from work. Twayi was a grocer while other members of the team were employed as masons, tailors, carpenters, tradesmen and clerks. He claimed that there were ' 120 Kaffir clubs' in the OFS although there were no leagues or cup competitions. This figure appears to be exaggerated because football was still in its infancy in the Orange Free State while the more institutionalised white game comprised a dozen clubs. Moreover in response to a question whether they played against white teams, Twayi answered 'Yes we play against white [sic] at Krontstadt, Jagersfontein, Heilbron, and other places'. Roberts interjected by saying 'I've played for Jagersfontein against Joseph's team' and Twayi remarked: 'That's quite right, Mr Roberts' ${ }^{88}$ In the light of the highly stratified and racist society in which the tourists resided these instances of matches between black and white cricket and soccer teams is very significant.

In response to a question on the on-going crisis with the South African Republic, Twayi said 'Sir, if Queen Victoria fights we fight for her, and 25,000 Basutos march through the Orange Free State to have their revenge'. ${ }^{89}$ The reporter exclaimed 'God save the Queen! Is that a fact Joseph?' to which Twayi replied: 'As true as the white mother is sitting on 
the throne'. ${ }^{90}$ Twayi's loyalty to Britain was also evident at the function held in honour of the visiting team after their game against Hamilton. In his speech he was quoted as saying that 'he wished them to understand ... that although their skin was black, they were all loyal subjects of Her Majesty the Queen' ${ }^{91}$ The Evening Citizen reported that Twayi was surprised that President Kruger of the South African Republic had refused to accept the British proposals ${ }^{92}$ (Chamberlain's terms of an unconditional five-year franchise for the Uitlanders).

\section{The South African War and imperial loyalty}

The touring team played one game in Ireland against Belfast Celtic and then returned to England via Liverpool where they met Everton in front of 4,000 spectators. Again the opposition was far too strong for the South Africans who lost 9:3. The Liverpool Daily Post wrote that the game was one of 'Tutor versus Pupil ... [and] this is what we understand the aborigines of South Africa have come here for; they want to discover the art of British athleticism, as probably others on the continent from which they come will soon solve the secret of another kind of British proficiency'. ${ }^{93}$ With the tension between Britain and the Boer republics escalating, The Football Echo and Sports Gazette noted that in the case of war 'it will be rather a joke if we keep on playing against the enemy. Civilized war is equal to many queer emergencies and there is no fear that the Kaffirs will be hauled into prison' ${ }^{94}$ War broke out between Britain and the South African Republic and her ally the Orange Free State on 11 October 1899. In an interview Twayi claimed to 'like England very much for its freedom. The people are so good to us, and they treat us splendidly. Their kindness makes me rejoice, for we Kaffirs have no freedom allowed by the Boers ... If the British fight we fight for them, for we would like our revenge'. 95 Twayi's comments were not isolated remarks; similar statements were regularly reported while the team was on tour.

Odendaal has argued that the 'political awareness of the new [African] class' in South Africa was influenced by the role of Christian missionaries; the non-racial constitution in the Cape; and by economic integration. ${ }^{96}$ In the case of Twayi his political consciousness 
can be understood in relation to the latter issue and in the context of the Orange Free State, the role of the church was certainly evident. Although the Hamilton Herald suggested that members of the team had been educated at the Lovedale Mission in the Cape, ${ }^{97}$ this is unlikely because Twayi said in an interview that he had been educated by the Wesleyans in Bloemfontein. ${ }^{98}$ African political activity was not as prominent and established as in the Cape prior to the South African War, there was nonetheless political activity. ${ }^{99}$ The black newspaper Imvo Zabantsundu edited by John Tengo Jabavu was circulated in the Orange Free State. Indeed the newspaper reported on black cricket matches played between Orange Free State teams and visiting players from the Cape in the early 1890s. ${ }^{100}$ Despite references to football games played between black and white teams in rural towns such as Jagersfontein, 'there were no pretensions about political, economic and social equality’ in Orange Free State society more broadly. ${ }^{101}$ Moreover, 'Republican administrators did not wish to encourage acculturation and assimilation'. ${ }^{102}$ Although in towns such as Jagersfontein where the diamond mine was the primary economic activity and employer, influential figures in the mining industry may well have had more sway than the local magistrate and in turn 'permitted' such games to take place.

According to historian Bill Nasson, for blacks in the Cape 'who faced Boer republicanism, the war ... was a battle to preserve rights, liberties and customs as citizens and subjects under an existing colonial order' ${ }^{103}$ In the Orange Free State 'they hoped that a British victory would result in the extension of idealised British non-racial ideals over the Afrikaner Republics’ ${ }^{104}$ For Twayi this was certainly the ideal. ${ }^{105}$ His position falls within the category identified by Nasson as 'patriotic consensus' rather than the pacifism of Jabavu. ${ }^{106}$ The rescheduled game against Aston Villa was played on 20 November 1899 watched by 4,000 spectators; the home side won easily (7:4). The significance of the game is that the takings from the match totalled $£ 61$ and the South Africans suggested this be donated to the Birmingham Daily Mail Reservists' Fund in support of the British war effort. In addition, the South Africans wore red, white and blue ribbons on their orange shirts during the game 'as a manifestation of their loyalty to the Queen'. ${ }^{107}$ Additional collections were taken for the Football Association War Fund. 


\section{Sporting contest}

After the opening game in Newcastle the visiting team's style of play was referred to as 'very peculiar'. ${ }^{108}$ In many of the games played the difference in standard and ability was all too evident; on occasion the home side goalkeeper played striker and the home goal was left unattended. Despite the South Africans' 'primitive ... idea of the game' ${ }^{109}$ they scored in all but one of the games played on tour and in some matches found the back of the net as many as six times, ${ }^{110}$ although admittedly many of these goals were scored from penalties deliberately conceded by the home side. Opposing sides did not seem to take the encounters particularly seriously and saw the games as practice matches. The press reported variously that the games offered 'plenty of amusement', 111 a 'comicsketch' 112 and that the 'contestants caus[ed] ... roars of laughter' ${ }^{113}$ The Football Evening News suggested 'any junior team in the country would beat them'. ${ }^{114}$ The Berkshire Chronicle reported that 'the Kaffirs might be able to give a junior team a good game, for some of them are speedy and they adopt worrying tactics but they have little knowledge of what to do with the ball'. ${ }^{115}$ And The Richmond and Twickenham Times reported:

Whatever the cause, it appeared almost impossible for 'Mr Kaffir' to kick a ball properly, even under the easiest of conditions. And then when a man was going to kick, his fellow-blacks usually rushed jabbering at him and spoiled the effort. And how they appeared to enjoy stealing the ball from one another ... For instance, they were not afraid of using their heads, but usually did so to the advantage of their opponents ... The last goal was the funniest of the match. When the five Kaffirs who were taking care of the ball approached the goal mouth, Richmond's two backs and the custodian got out of the way, and left their assailants to their own devices. There ensued a scene of really pantomimic humour. First one and then the other kicked the ball this way and that, but never in the desired direction, till at last one little fellow trotted gingerly up to it and put it into the goal with a very soft kick indeed. Then the crowd ceased holding their aching sides. ${ }^{116}$ 
Despite what appears to be the light hearted nature of many of these encounters the South Africans seemed to take the matches seriously and this was often noted in the press. The Tottenham and Stamford Hill Times reported that 'several of the men showed excellent staying power and speed'. Significantly, 'among the visitors praise is especially due to the goalkeeper who saved brilliantly at times, and who, we understand, has been approached with a view of enlistment in one of the First League teams' ${ }^{117}$ Against a Richmond side the South African goalkeeper, Adolph, 'played splendidly, saving time after time very hot shots that were meant seriously by the Richmond team to find the net'. ${ }^{118}$ Throughout the tour Adolph was frequently singled out for praise and it was reported that he would make a worthy addition to any of the top teams in Britain.

On 16 December the South Africans played against the Southern League, Division 1 side, Sheppey United. The Sheerness Times and General Advertiser reported that the South Africans were 'certainly superior to ... the German team that visited Sheerness three years ago'. ${ }^{119}$ Despite the poor results, crowds were large and the touring team remained popular. Matches were scheduled to be played well into February 1900 in Britain and the team had also been invited to play in Germany and Austria. However, in late December 1899 The Midland Daily Telegraph reported that the visitors' match against Coventry, scheduled for January 1900, had been cancelled and 'considerable disappointment has been caused to the Coventry City Football Club officials ... it was believed the novelty of the match would prove a great attraction'. The tourists explained that ticket restrictions meant they were only permitted to be out of the country for a six month period. ${ }^{120}$ Games against Ilkeston and Walsall also had to be cancelled.

It appears that the tour was not a financial success and nothing came of the invitations to tour Germany and Austria. The South Africans did however play one game in northern France against the Sporting Club Tourcoing in Roubaix. Watched by a large crowd that included amateur players from Brussels and Paris, the South Africans were victorious and won by three goals to one. Adolph was referred to as the best goalkeeper ever seen in the area, and the game was adjudged 'excellent and sensational'. ${ }^{121}$ This represented the team's only victory in the 49 games it played while on tour. In many of the towns visited, 
the South Africans were greeted by crowds at railway stations, were taken to view local sights of interest and numerous evening functions were held in their honour. These were often attended by town dignitaries including mayors, councillors and business people. The South Africans boarded their steamer bound for Cape Town on 6 January 1900.

\section{Conclusion}

On the eve of the South African War the Orange Free State football team travelled to Britain, and in four months played 49 matches in unfamiliar conditions and against firstclass amateur and professional opposition. This was the first South African football side to play abroad and despite the trying circumstances of racism, ridicule and humiliation reported in the British press, the team was fêted and well-supported throughout its tour. Although the results on the football pitch were far from encouraging, if we consider these in the light of the poor results all South African teams initially achieved against British cricket and rugby teams in particular, the footballers' tour followed a similar pattern and this does not detract from its importance. Far from being insignificant in South African and British sports history, the 1899 touring football team deserves recognition for the pioneering role played in late nineteenth-century football.

\section{Notes}

${ }^{1}$ Earlier versions of this article were presented at the North American Society for Sports History, Asheville, North Carolina, 22-25 May 2009 and the $3^{\text {rd }}$ Sport, Race and Ethnicity Conference: Beyond Boundaries: Race and Ethnicity in Modern Sport, Cave Hill, Barbados 15-18 July 2010. I would like to thank Karel Schoeman in particular for sharing his wonderful insights with me on numerous occasions. In addition a number of people assisted in gathering material and commenting on earlier versions of this paper. They include: Peter Alegi, Ken Cohen, Bob Edgar, Lloyd Hill, Emmanuelle Labeau, Ian Nannestad, André Odendaal, Rothea Pelser, Ben Shepard, Phil Vasili and a number of club historians. A limitation in this article is the lack of African perspectives. Only interviews conducted with Joseph Twayi were published in the British press while nothing seems to have been published in South Africa. The author met with Vuzi Twayi, the great-grandson of Joseph in Bloemfontein in May 2009 and Sandile Twayi, the grandson in June 2010 and both were unable to shed any new evidence or insights on their grandfather, great-grandfather and the touring team.

${ }^{2}$ In any analysis of South Africa a consideration of the use of racial categories and terminology is necessary. A range of derogatory racial terms were used and these include 'kaffir', 'native' and 'nigger', among others. For the purposes of this analysis I have used these words in direct quotations.

${ }^{3}$ Scottish Sport, 19 September 1899.

${ }^{4}$ A. Odendaal, 'South Africa's Black Victorians: Sport and Society in South Africa in the Nineteenth Century', in J.A. Mangan (ed.), Pleasure, Profit, Proselytism: British Culture and Sport at Home and Abroad, 1700-1914 (London: Frank Cass, 1988). See also A. Odendaal, The Story of an African Game: Black Cricketers and the Unmasking of one of Cricket's Greatest Myths, South Africa, 1850-2003 (Cape 
Town: David Philip, 2003); and C. Thomas (ed.), Sport and Liberation in South Africa: Reflections and Suggestions.(University of Fort Hare National Heritage and Cultural Studies Centre; and Department of Sport and Recreation, 2006).

${ }^{5}$ See in particular P. Alegi, Laduma! Soccer, Politics and Society in South Africa (Scottsville: University of KwaZulu-Natal Press, 2004); and P. Alegi and C. Bolsmann (eds), South Africa and the Global Game: Football, Apartheid and Beyond (London: Routledge, 2010).

${ }^{6}$ G.A. Parker, (ed.), South African Sports (London: Sampson Low, Marston \& Co., 1897), pp. 86, 89; L. Hill, 'Football as Code: The Social Diffusion of 'Soccer' in South Africa', in Alegi and Bolsmann (eds), South Africa and the Global Game.

${ }^{7}$ A. Gibson and W. Pickford, Football and the Men who Made it (Cape Town: McConnel \& Co., 1906), p. 233.

${ }^{8}$ Alegi, Laduma!, p. 16.

${ }^{9}$ T. Couzens, 'An Introduction to the History of Football in South Africa', in B. Bozzoli (ed.), Town and Countryside in the Transvaal: Capitalist Penetration and Popular Response (Johannesburg: Ravan Press, 1983), p. 203.

${ }^{10}$ Diamond Fields Advertiser, 6 October 1892.

${ }^{11}$ The Cape Argus, 14 August 1894.

${ }^{12}$ Parker, South African Sports, p. 86.

${ }^{13}$ Ibid; De Express en Oranjevrijstatsche Advertentieblad, 26 August 1890.

${ }^{14}$ The Friend of the Free State and Bloemfontein Gazette, 12 September 1890.

${ }^{15}$ The Friend of the Free State and Bloemfontein Gazette, 22 September 1891.

${ }^{16}$ The Friend of the Free State and Bloemfontein Gazette, 26 April 1892.

${ }^{17}$ Heilbron defeated Bethlehem 7:0 and Lindley 2:0.

${ }^{18}$ For discussion on the Corinthian Football Club see F. Creek, A History of the Corinthian Football Club (London: Longmans, Green \& Co, 1933); and R. Cavallini, Play Up Corinth: A History of the Corinthian Football Club (Chalford Stroud: Stadia, 2007).

${ }^{19}$ N.L. Jackson, Association Football (London: George Newnes, 1899).

${ }^{20}$ The Friend of the Free State and Bloemfontein Gazette, 6 August 1897.

${ }^{21}$ There was also a sizable English speaking community in the Orange Free State that would have participated in and promoted the spread of the game. See S. F. Malan Die Rol van J. Geo. Fraser in die Vrystaat, 1863-1927 (Pretoria Archives Year Book for South African History, 1974).

${ }^{22}$ The Friend of the Free State and Bloemfontein Gazette, 3 September 1897.

${ }^{23}$ Odendaal, 'South Africa’s Black Victorians’, p. 196.

${ }^{24}$ Ibid., p. 197.

${ }^{25}$ Ibid., p. 198.

${ }^{26}$ Ibid., p. 199

${ }^{27}$ The Friend of the Free State and Bloemfontein Gazette, 10 July 1891 and 28 January 1896.

${ }^{28}$ Couzens, 'An Introduction to the History of Football', pp. 200-203.

${ }^{29}$ Alegi, Laduma!, p. 18; Couzens ‘An Introduction to the History of Football’, p. 200.

${ }^{30}$ Particular thanks to Ian Nannestad of Soccer History for this information.

${ }^{31}$ Beck, P. Scoring for Britain: International Football and International Politics 1900-1939 (London: Frank Cass, 1999), p. 53.

${ }^{32}$ D. Goldblatt, The Ball is Round: A Global History of Football (London: Penguin, 2006), p. 140.

${ }^{33} \mathrm{http}: / /$ www.canadiansoccerhistory.com/canadiantours/canadiantours1.htm Accessed 6 April 2009.

${ }^{34}$ A. Mallet, The Black Lords of Summer: The Story of the 1868 Aboriginal Tour of England and beyond (St Lucia: University of Queensland Press, 2002).

${ }^{35}$ R. Archer and A. Bouillon, The South African Game: Sport and Racism (London: Zed Press, 1983), pp. 62, 80.

36 This side played 74 games in Britain (Won 49; Drew 5; Lost 20). See G. Ryan, Forerunners to the All Blacks: The 1888-89 New Zealand Native Football Team in Britain, Australia and New Zealand (Christchurch: Canterbury University Press, 1993).

${ }^{37}$ See I. Nannestad, 'The Story of John Walker, Scotland's First Black Professional Footballer' Soccer History, 22,(2009), pp. 8-12, P. Vasili, The First Black Footballer, Arthur Wharton 1865-1930: An Absence of Memory (London: Frank Cass, 1998), and P. Vasili, Colouring over the White Line: The History of Black Footballers in Britain (Edinburgh: Mainstream Publishing, 2000). 
${ }^{38}$ The Football Echo and Sports Gazette, Saturday 29 April 1899, p. 1.

${ }^{39}$ Manchester Times, Friday 30 June 1899.

${ }^{40}$ Scottish Sport, 18 July 1899, p. 3 and 11 July 1899, p. 1.

${ }^{41}$ The Friend of the Free State and Bloemfontein Gazette, 15 August 1899.

${ }^{42}$ Quoted in V. Bickford-Smith, Ethnic Pride and Racial Prejudice in Victorian Cape Town: Group

Identity and Social Practice, 1875-1902 (Cambridge: Cambridge University Press, 1995), p. 149.

43 The Cape Argus, 10 August 1899, p. 7.

${ }^{44}$ The Friend of the Free State and Bloemfontein Gazette, 1 September 1899.

${ }^{45}$ Cape Times, 21 September 1899, p. 5.

${ }^{46}$ The Football Evening News, 2 September 1899, p. 3.

${ }^{47}$ The Northern Echo, 8 September 1899, p. 4.

${ }^{48}$ The Football Evening News, 2 September 1899, p. 3.

${ }^{49}$ Sport and Play, 4 September 1899.

${ }^{50}$ B. Lindfors (ed.), Africans on Stage: Studies in Ethnological Show Business (Bloomington: Indiana University Press, 1999), p. vii.

${ }^{51}$ Z.S. Strother, 'Display of the Body Hottentot', in Lindfors (ed), Africans on Stage, p. 37.

${ }^{52}$ B. Lindfors, 'Charles Dickens and the Zulus', in Lindfors (ed), Africans on Stage, p. 67.

${ }^{53}$ S. Peacock, 'Africa Meets the Great Farini', in Lindfors (ed.), Africans on Stage, p. 86.

${ }^{54}$ V. Erlmann, “'Spectatorial Lust” The African Choir in England, 1891-1893', in Lindfors (ed.), Africans on Stage.

${ }^{55}$ John A. Hobson cited in Ibid., p. 110.

${ }^{56}$ Lindfors (ed.), Africans on Stage, p. xii.

${ }^{57}$ N. Parsons, “"Clicko” Franz Taaibosch, South African Bushman Entertainer in England, France, Cuba and the United States, 1908-1940', in Lindfors (ed.), Africans on Stage, p. 223. See N. Parsons, Clicko: The Wild Dancing Bushman (Auckland Park: Jacana Media, 2009).

${ }^{58}$ Quoted in B. Shephard, 'Showbiz Imperialism: The Case of Peter Lobengula', in J.M. MacKenzie (ed.), Imperialism and Popular Culture (Manchester: Manchester University Press, 1986), p97. See also B.

Shephard, Kitty and the Prince (London: Profile, 2003).

${ }^{59}$ A. Coombes, Reinventing Africa: Museums, Material Culture and Popular Imagination in late Victorian and Edwardian England (New Haven: Yale University Press, 1994), p. 85.

${ }^{60}$ See F. van der Merwe, 'Sirkusbaas Frank Fillis (1857-1921): Die Barnum van Suid-Afrika', South

African Journal of Cultural History, 16, 2 (2002), pp. 110-131.

${ }^{61}$ Shephard, 'Showbiz Imperialism', p. 98.

${ }^{62}$ Ibid.

${ }^{63}$ Shephard, 'Showbiz Imperialism’, p. 103.

64 'The Kaffir Kraal', The Daily Chronicle, 9 September 1899, p. 8.

${ }^{65}$ The Football Evening News, 2 September 1899, p. 3.

${ }^{66}$ Ibid.

${ }^{67}$ The Sporting Life, 6 September 1899, p. 3.

${ }^{68}$ Vasili, The First Black Footballer, p. 141.

${ }^{69}$ Beck, Scoring for Britain, p. 32.

${ }^{70}$ The Sporting Life, 30 September 1899, p. 3.

${ }^{71}$ Scottish Sport, 25 August 1899.

${ }^{72}$ The Newcastle Daily Journal, 6 September 1899.

${ }^{73}$ The Football News, 9 September 1899.

${ }^{74}$ Scottish Sport, 8 September 1899.

${ }^{75}$ Scottish Sport, 15 September 1899, p. 4.

76 'Against the Kaffirs: A Cape Town Player's Protest', Scottish Sport, 12 September 1899, p. 4.

77 'The Nigger Abroad', Sporting Times, 23 September 1899.

${ }^{78}$ See Bickford-Smith, V. Ethnic Pride and Racial Prejudice and Dubow, S. Scientific Racism in Modern South Africa Cambridge: Cambridge University Press, 1995.

${ }^{79}$ South Africa, 11 December 1897, p. 491.

${ }^{80}$ Ibid.

${ }^{81}$ Cited in 'The Game in Kaffirland', Scottish Sport, 19 September 1899.

${ }^{82}$ Scottish Sport, 19 September 1899. 
${ }^{83}$ Ibid.

${ }^{84}$ Football Sun, 9 September 1899, p. 1.

85 'The Kaffir Footballers: Twayi Interviewed', The Football News, 14 October 1899, p. 6.

${ }^{86}$ Odendaal, The Story of an African Game, p. 69. K. Schoeman, Bloemfontein: Die Onstaan van ' $n$ Stad 1846-1946 (Cape Town: Human \& Rousseau, 1980), p. 131.

${ }^{87}$ Scottish Sport, 19 September 1899.

${ }^{88}$ Ibid.

${ }^{89}$ Ibid.

90 Ibid.

91 'Kaffir Football Team in Hamilton', Hamilton Herald and Lanarkshire Weekly News, 22 September 1899, p. 6.

92 'A Kaffir on the Situation', Evening Citizen, 22 September 1899, p. 3.

${ }^{93}$ The Liverpool Daily News, 29 September 1899.

94 'The Kaffir Force', The Football Echo and Sports Gazette, 23 September 1899, p. 3.

95 'The Kaffir Footballers: Twayi Interviewed', The Football News, 14 October 1899.

${ }^{96}$ A. Odendaal, Vukani Bantu! The Beginnings of Black Protest Politics in South Africa to 1912 (Cape Town: David Philip, 1984), p. 3.

97 'The Kaffir Football Team in Hamilton', Hamilton Herald, 22 September 1899.

${ }^{98}$ Football Sun, 9 September 1899, p. 1.

${ }^{99}$ See in particular Odendaal, Vukani Bantu!, pp. 20-23.

${ }^{100}$ Ibid., p. 23.

101 Ibid., p. 19

102 Ibid., p. 20.

${ }^{103}$ B. Nasson, Abraham Esau's War: A Black South African War in the Cape, 1899-1902 (Cambridge: Cambridge University Press, 1991), p. 11. See also P. Warwick Black People and the South African War, 1899-1902 (Cambridge: Cambridge University Press, 1983).

104 Odendaal, Vukani Bantu!, p. 30.

${ }^{105}$ On his return to Bloemfontein Joseph Twayi became active in local politics. Twayi was treasurer of the South African Native National Congress in 1915, the forerunner of the African National Congress. See numerous references to this activity in Odendaal, Vukani Bantu!

${ }^{106}$ Nasson, Abraham Esau's War, pp 33-34.

${ }^{107}$ Birmingham Daily Post, 21 November 1899, p. 8.

${ }^{108}$ The Sportsman, 6 September 1899, p. 8.

${ }^{109}$ Football Echo, 14 October 1899.

${ }^{110}$ The results of all the matches are (all were played in 1899 except the last two in January 1900): 5 September Newcastle United (6:3); 6 September Sunderland (5:3); 7 September Middlesbrough (7:3); 9 September Scarborough (9:3); 11 September Hibernian (3:2); 13 September Morton (7:6); 15 September Ayr Parkhouse (6:5); 16 September Hamilton Academicals (6:5); 20 September Dundee (6:4); 21 September Celtic (Glasgow) (2:0); 23 September Celtic (Belfast) (5:3); 27 September Everton (9:3); 2 October Burton Swifts (5:4); 4 October Manchester City (5:3); 7 October Leicester Fosse (7:3); 9 October Northampton Town (7:4); 12 October Nottingham Forest (6:3); 14 October Barnsley (8:5); 18 October Derby County (6:6); 21 October Lincoln City Reserves (9:5); 23 October Sheffield United (7:2); 25 October Loughborough (4:7); 28 October Bolton Wanderers (13:3); 30 October Burnley (7:6); 6 November Preston North End (5:3); 7 November Bradford \& District (8:6); 11 November Wrexham (5:4); 15 November Druids (4:3); 16 November Shrewsbury Town (7:5); 20 November Aston Villa (7:4): 22 November West Bromwich Albion (11:6); 25 November Wellingborough (7:5); 27 November Tottenham Hotspur (6:4); 29 November Richmond Association (8:4); 4 December Luton Town (8:6); 6 December Portsmouth Reserves (7:3); 7 December Ryde (5:3); 9 December Cowes (5:3); 13 December Gravesend United (5:4); 16 December Sheppey United (4:3); 17 December Sporting Club Tourcoing (1:3); 20 December Reading (9:5): 23 December Ealing (abandoned due to weather); 25 December Brentford (3:2); 26 December Brighton United (10:5); 27 December Dorset County (8:3); 30 December Bournemouth (1:2); 1 January 1900 Bristol City (6:5); and 2 January 1900 Aberdare (7:3).

${ }^{111}$ The Scotsman, 12 September 1899.

${ }^{112}$ Glasgow Herald, 12 September 1899.

${ }^{113}$ North Wales Guardian, 17 November 1899, p. 7. 


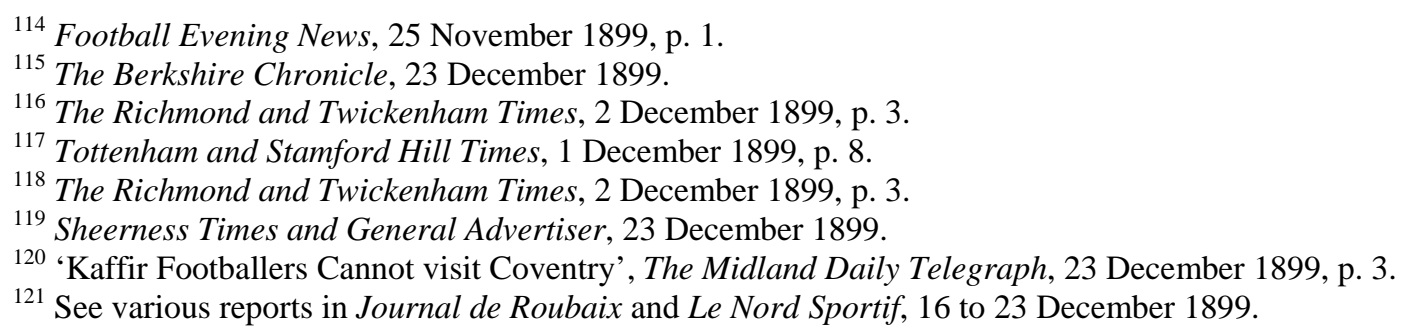

\section{References}

Alegi, P. Laduma! Soccer, Politics and Society in South Africa. Scottsville: University of KwaZulu-Natal Press. 2004.

Alegi, P. and Bolsmann, C. (eds.). South Africa and the Global Game: Football, Apartheid and Beyond. London: Routledge. 2010.

Archer, R. and Bouillon, A, The South African Game: Sport and Racism. London: Zed Press. 1983.

Beck, P. Scoring for Britain: International Football and International Politics 19001939. London: Frank Cass. 1999.

Bickford-Smith, V. Ethnic Pride and Racial Prejudice in Victorian Cape Town: Group Identity and Social Practice, 1875-1902. Cambridge: Cambridge University Press. 1995.

Cavallini, R. Play up Corinth: A History of the Corinthian Football Club. Chalford Stroud: Stadia. 2007.

Coombes, A.E. Reinventing Africa: Museums, Material Culture and Popular Imagination in late Victorian and Edwardian England. New Haven: Yale University Press. 1994.

Couzens, T. 'An Introduction to the History of Football in South Africa'. In B. Bozzoli (ed.). Town and Countryside in the Transvaal: Capitalist Penetration and Popular Response. Johannesburg: Ravan Press. 1983. 
Creek, F. A History of the Corinthian Football Club. London: Longmans, Green \& Co. 1933.

Dubow, S. Scientific Racism in Modern South Africa Cambridge: Cambridge University Press, 1995.

Erlmann, V. ““Spectatorial Lust”: The African Choir in England, 1891-1893’. In B. Lindfors (ed.). Africans on Stage: Studies in Ethnological Show Business. Bloomington: Indiana University Press. 1999.

Gibson, A. and Pickford, W. Football and the Men who Made it. Cape Town: McConnel \& Co. 1906.

Goldblatt, D. The Ball is Round: A Global History of Football. London: Penguin. 2006.

Hill, L. 'Football as Code: The Social Diffusion of 'Soccer' in South Africa'. In P. Alegi and C. Bolsmann (eds.). South Africa and the Global Game: Football, Apartheid and Beyond. London: Routledge. (forthcoming).

Jackson, N.L. Association Football. London: George Newnes. 1899.

Lindfors, B. (ed). Africans on Stage: Studies in Ethnological Show Business.

Bloomington: Indiana University Press. 1999.

Lindfors, B. 'Charles Dickens and the Zulus'. In B. Lindfors (ed.). Africans on Stage: Studies in Ethnological Show Business. Bloomington: Indiana University Press. 1999.

Malan, S. F. Die Rol van J. Geo. Fraser in die Vrystaat, 1863-1927. Pretoria: Archives Year Book for South African History, 1974. 
Mallet, A. The Black Lords of Summer: The Story of the 1868 Aboriginal Tour of England and Beyond. St Lucia: University of Queensland Press. 2002.

Nannestad, I. 'The Story of John Walker, Scotland's First Black Professional Footballer' Soccer History, 22,(2009), 8-12.

Nasson, B. Abraham Esau's War: A Black South African War in the Cape, 1899-1902. Cambridge: Cambridge University Press. 1991.

Odendaal, A. Vukani Bantu! The Beginnings of Black Protest Politics in South Africa to 1912. Cape Town: David Philip. 1984.

Odendaal, A. 'South Africa’s Black Victorians: Sport and Society in South Africa in the Nineteenth Century'. In J.A. Mangan (ed.). Pleasure, Profit, Proselytism: British Culture and Sport at Home and Abroad 1700-1914. London: Frank Cass. 1988.

Odendaal, A. The Story of an African Game: Black Cricketers and the Unmasking of one of Cricket's Greatest Myths, South Africa, 1850-2003. Cape Town: David Philip. 2003.

Parker, G.A. (ed.). South African Sports. London: Sampson Low, Marston \& Co. 1897.

Parsons, N. ““Clicko” Franz Taaibosch, South African Bushman Entertainer in England, France, Cuba and the United States, 1908-1940'. In B. Lindfors (ed). Africans on Stage: Studies in Ethnological Show Business. Bloomington: Indiana University Press. 1999.

Parsons, N. Clicko: The Wild Dancing Bushman. Auckland Park: Jacana Media, 2009.

Peacock, S. 'Africa Meets the Great Farini'. In B. Lindfors (ed.). Africans on Stage: Studies in Ethnological Show Business. Bloomington: Indiana University Press. 1999. 
Ryan, G. Forerunners to the All Blacks: The 1888-89 New Zealand Native Football Team in Britain, Australia and New Zealand. Christchurch: Canterbury University Press. 1993.

Schoeman, K. Bloemfontein: Die Onstaan van 'n Stad 1846-1946. Cape Town: Human \& Rousseau. 1980.

Shephard, B. ‘Showbiz Imperialism: The Case of Peter Lobengula’. In J.M. MacKenzie (ed.). Imperialism and Popular Culture. Manchester: Manchester University Press. 1986.

Shephard, B. Kitty and the Prince. London: Profile Books. 2003.

Strother, Z.S. 'Display of the Body Hottentot'. In B. Lindfors (ed.) Africans on Stage: Studies in Ethnological Show Business. Bloomington: Indiana University Press. 1999.

Thomas, C. (ed). Sport and Liberation in South Africa: Reflections and Suggestions. University of Fort Hare National Heritage and Cultural Studies Centre \& Department of Sport and Recreation. 2006.

van der Merwe, F. ‘Sirkusbaas Frank Fillis (1857-1921): Die Barnum van Suid-Afrika’, South African Journal of Cultural History, 16, 2 (2002), 110-131.

Vasili, P. The First Black Footballer, Arthur Wharton 1865-1930: An Absence of Memory. London: Frank Cass. 1998.

Vasili, P. Colouring over the White Line: The History of Black Footballers in Britain. Edinburgh: Mainstream Publishing. 2000.

Walvin, J. The People's Game: A Social History of British Football. London: Allen Lane. 1975. 
Warwick, P. Black People and the South African War, 1899-1902. Cambridge:

Cambridge University Press, 1983. 